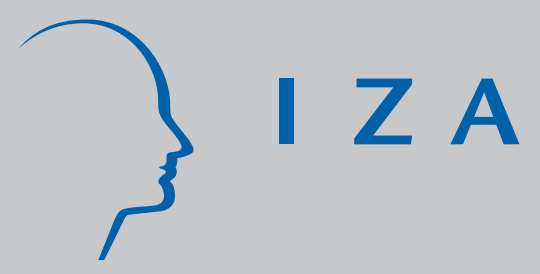

IZA DP No. 2506

Multinational Companies, Backward Linkages and Labour Demand Elasticities

Holger Görg

Michael Henry

Eric Strobl

Frank Walsh

December 2006 


\title{
Multinational Companies, Backward Linkages and Labour Demand Elasticities
}

\author{
Holger Görg \\ GEP, University of Nottingham and IZA Bonn \\ Michael Henry \\ Aston Business School, Aston University \\ Eric Strobl \\ Ecole Polytechnique Paris and IZA Bonn \\ Frank Walsh \\ University College Dublin
}

\section{Discussion Paper No. 2506 \\ December 2006}

\author{
IZA \\ P.O. Box 7240 \\ 53072 Bonn \\ Germany \\ Phone: +49-228-3894-0 \\ Fax: +49-228-3894-180 \\ E-mail: iza@iza.org
}

\begin{abstract}
Any opinions expressed here are those of the author(s) and not those of the institute. Research disseminated by IZA may include views on policy, but the institute itself takes no institutional policy positions.

The Institute for the Study of Labor (IZA) in Bonn is a local and virtual international research center and a place of communication between science, politics and business. IZA is an independent nonprofit company supported by Deutsche Post World Net. The center is associated with the University of Bonn and offers a stimulating research environment through its research networks, research support, and visitors and doctoral programs. IZA engages in (i) original and internationally competitive research in all fields of labor economics, (ii) development of policy concepts, and (iii) dissemination of research results and concepts to the interested public.
\end{abstract}

IZA Discussion Papers often represent preliminary work and are circulated to encourage discussion. Citation of such a paper should account for its provisional character. A revised version may be available directly from the author. 
IZA Discussion Paper No. 2506

December 2006

\section{ABSTRACT \\ Multinational Companies, Backward Linkages and Labour Demand Elasticities*}

This paper investigates the link between nationality of ownership and wage elasticities of labour demand at the level of the plant. In particular, we examine whether labour demand in multinationals becomes less elastic with respect to the wage if the plant has backward linkages with the local economy. Our empirical evidence, based on a rich plant level dataset, shows that the extent of local linkages indeed generally reduces the wage elasticity of labour demand. This result is economically important and holds for a number of different specifications.

JEL Classification: F23, J23, L23

Keywords: labour demand, elasticities, linkages, multinational companies

Corresponding author:

Holger Görg

School of Economics

University of Nottingham

University Park

Nottingham NG7 2RD

United Kingdom

E-mail: holger.gorg@nottingham.ac.uk

\footnotetext{
* An earlier version of the paper was presented at workshops in Stockholm, Nottingham and Dundee. The authors are grateful to Andrew Bernard, Daniel Bernhofen, Patrik Gustavsson Tingvall, Lars Lundberg, Hassan Molana, Catia Montagna for helpful comments. Holger Görg gratefully acknowledges financial support from the Leverhulme Trust (Programme Grant No. F114/BF) and Michael Henry from the ESRC (Grant No. RES-000-22-0468).
} 


\section{Introduction}

It has been well established in the empirical literature that workers in industrialised countries have experienced higher job insecurity over the last few decades, both in terms of higher volatility of employment spells and earnings (e.g., OECD 1997). “Globalisation” has been made at least partly responsible for these trends, certainly in the popular debate as well as among academics (e.g, Rodrik, 1997; Scheve and Slaughter, 2004). Of all the drivers of globalisation - trade, migration of workers, and foreign direct investment (FDI) - FDI is probably the most visible. It is also likely to be, at the margin, the most important aspect of globalisation in economic terms. For instance, over the last two decades global FDI flows have grown at least twice as fast as trade, now well exceeding $\$ 500$ billion and resulting in a total stock of more than $\$ 8$ billion (United Nations, 2004).

It is not surprising then, that the potential "footloose" nature of FDI in response to changes in production costs elsewhere has raised some concern about the jobs created through FDI, despite the generally higher wages associated with such employment (e.g., Lipsey and Sjöholm, 2004; Girma and Görg, 2007). As a matter of fact, these fears have recently come to the fore in the wake of a number of plant closures by high profile multinationals in Europe, often attributed to lower wages elsewhere. For example, the Japanese multinational Sony announced the closure of one of its plants in Wales in June 2005, with the resulting loss of 650 jobs due to the availability of lower production costs elsewhere. ${ }^{1}$

It is important to note, however, that the potential "footloose" nature of FDI is only one possible response to changes in production costs. ${ }^{2}$ Alternatively,

\footnotetext{
${ }^{1}$ http://www.personneltoday.co.uk/Articles/2005/06/30/30593/Sony+slashes+650+UK+jobs.htm

2 Bernard and Sjöholm (2003) and Görg and Strobl (2003) find that multinationals have higher exit probabilities than comparable domestic plants, a finding in line with this argument.
} 
multinationals may, rather than completely shutting down production, simply downsize their operations and shed labour in the light of the availability of cheaper labour elsewhere. Thus, if one is to capture the complete picture of lower job stability in multinationals then one arguably also needs to investigate differences in the wage elasticity of multinationals relative to the indigenous industry.

In this regard, there are only a few studies which compare the wage elasticity of labour demand in multinationals and domestic firms. Fabbri et al. (2003) discuss the issue and illustrate the theory with a standard neo-classical labour demand framework. Their idea is quite straightforward: multinationals are part of global production networks and, within these networks, can more easily transfer production in response to changes in costs (in particular wages). Using industry level data they find an increase in wage elasticities of labour demand (conditional on output) over time for low skilled US and UK manufacturing workers and argue that increased activity of multinationals may be partially responsible for this. By contrast BarbaNavaretti et al (2003) in a cross country firm level study of a group of European countries find that, in most countries, multinationals adjust their labour demand more rapidly than domestic firms in response to shocks, but have a more inelastic demand curve with respect to wages. They argue that multinationals have a more rigid demand for labour due to differences in skill structure. ${ }^{3}$

The current paper re-examines the link between nationality of ownership and the wage elasticity of labour demand, but specifically investigates whether efforts at integrating multinationals in the local economy through backward linkages can

\footnotetext{
${ }^{3}$ The paper by Konings and Murphy (2001) is also somewhat related. They look at the extent to which multinationals substitute employment towards parent plants in response to wage changes. They find evidence of substitution between EU parent firms and their subsidiaries rather than towards low wage subsidiaries outside the EU. In addition, Slaughter (2001) looks at labour demand elasticities in the US to see whether increased openness to trade has increased the demand elasticity and found little support for this hypothesis.
} 
reduce their volatile nature by affecting their elasticity of labour demand., ${ }^{4,5}$ Our argument that this is likely to be the case rests on the idea that locally purchased inputs may be more difficult to substitute for labour than other inputs. This may be plausible under the assumption that locally sourced inputs are to some degree "specific" due to, e.g., better quality and availability, or lower transport costs than imported inputs. To discuss these points in more detail we present a simple framework that highlights how such channels are likely to affect labour demand.

Using a rich plant level data set for manufacturing plants in the Republic of Ireland we then empirically investigate whether wage elasticities depend on the extent of local backward linkages and whether this is more important for foreign multinationals than for indigenous firms. Arguably, Ireland is a particularly interesting case study in this regard given that its manufacturing industry is heavily dependent on foreign multinationals, and also the fact that foreign plants account for about half of total employment. Moreover, Ireland has operated a number of explicit policy programmes to foster linkages between foreign multinationals and domestic suppliers (Ruane, 2001).

The remainder of the paper is structured as follows. Section 2 provides the theoretical background for our analysis. Section 3 describes the data sources. Section 4 outlines the empirical approach and discussed our results. Section 5 concludes.

\section{Theoretical background}

We consider a foreign owned plant as a subsidiary of a multinational firm that has already decided to locate the plant, thereby incurring fixed costs, and also has an

\footnotetext{
${ }^{4}$ We do not consider plant exit in this paper.

${ }^{5}$ Our paper is, hence, also related to the recent literature on productivity spillovers from FDI, which argues that spillovers are most likely to occur through multinationals' backward linkages with domestic suppliers (e.g., Driffield et al., 2002, Javorcik, 2004).
} 
upward sloping marginal cost curve. Because the firm has several plants in different locations we assume the plant is a price taker and the multinational firm will minimise costs by equalising marginal costs across all plants. The head office may have market power but will treat each plant as a profit maximising firm where the output price equals the marginal cost across all plants. Thus the subsidiary will look like a textbook competitive firm where the plant manager has to maximise profits choosing output at a price fixed by head office, where the price equals the marginal cost of plants in other locations. This means that for a foreign affiliate located in a host country we assume the impact of an increase in wages on the output price, which is a function of the firm's global production costs, to be negligible. The plant is hence assumed to have a fixed price, a u-shaped average cost curve due to fixed costs and increasing marginal costs. ${ }^{6}$

In order to illustrate our argument as to why backward linkages with domestic suppliers may impact on labour demand elasticities we summarise the well known neo-classical conditional labour demand model. ${ }^{7}$ A price taking affiliate has a production function with $n$ inputs:

$$
y=f\left(x_{1}, \ldots x_{n}\right)
$$

The price of each factor $i$ is $w_{i}$ and total costs are $c=F+w_{1} x_{1}+w_{2} x_{2} \ldots+w_{n} x_{n}$. The Lagrangian function for cost minimisation is:

$$
\ell=w_{1} x_{1}+w_{2} x_{2} . .+w_{n} x_{n}+\lambda\left[y-f\left(x_{1} . . x_{n}\right)\right]
$$

The share of any factor $j$ in variable costs is $s_{j}$. The elasticity of substitution between labour (factor 1 ) and any other factor $j$ is $\sigma_{1 j}$.

\footnotetext{
${ }^{6}$ The plant may make profits in contrast to a competitive firm since we do not expect free entry to dissipate profits.

${ }^{7}$ See also Fabbri et al. al (2003) who use this framework to motivate differences in labour demand elasticities between foreign and domestic owned firms, or Hammermesh (1993) for a more general discussion.
} 
We show in the appendix that the labour demand elasticity conditional on output is:

$$
\eta_{11}^{*}=\frac{\partial x_{1}}{\partial w_{1}} \frac{w_{1}}{x_{1}}=\frac{\sum_{j \neq 1}^{n} \sigma_{1 j} f_{j} x_{j}}{\sum_{i=1}^{n} f_{i} x_{i}}=\sum_{j=1}^{n} \sigma_{1 j} s_{j}
$$

Other things equal, equation (3) tells us that the labour demand elasticity is determined by two aspects, namely, the elasticity of substitution between labour and the other factor $j$, and the share of factor $j$. $^{8}$

There are a number of issues with regard to (3) that are important to point out for our task at hand. First, with regard to labour's share in total cost, since theoretical frameworks outlining multinational firms suggest that such firms will have fixed costs (e.g. Markusen, 2002), one should be wary about looking at labour's share in output as a proxy for $s$, as it is labour's share in variable costs that is relevant to the demand elasticity. For example, affiliates whose parent has incurred significant advertising or R\&D costs may have very high output per worker, so that labour costs may be a small share of output but a much larger share of variable costs.

Equation (3) also suggests that, if locally purchased inputs are more difficult to substitute for labour than other inputs (low $\sigma$ ) firms that purchase more local inputs will have smaller elasticities. This may be plausible under the assumption that locally sourced inputs are to some degree "specific" due to, e.g., better quality and availability, or lower transport costs than imported inputs. As an example, a multinational firm switching sourcing from a supplier abroad to a local is then in a better position to obtain specific design or quality standards, perhaps with the help of

\footnotetext{
${ }^{8}$ While equation (3) is well known we derive it explicitly in the Appendix to point out two important points that will be relevant to our analysis. First while much of the literature using equation (3) assumes constant returns to scale, this is not necessary. Secondly, $s_{l}$ is labour's share of variable costs, not total costs. A firm may incur non-recoverable fixed costs, e.g., from advertising or R\&D, or other start-up costs to enhance output per worker but these will not affect the calculation in equation (3).
} 
providing assistance to the local supplier in the first instance. ${ }^{9}$ Therefore, it may be less likely to substitute the locally sourced input for labour than the previously imported input. $^{10}$

One of Marshalls well known rules of labour demand is that it will be less elastic the more elastic is the supply of other inputs. ${ }^{11}$ The intuition is that if the supply of another input (say capital) is steep, a rise in wages will increase the demand for capital as firms substitute from labour into capital, but this will drive up the price of capital limiting the degree to which firms will substitute. For the two factor case, Appendix 2 shows how an increase in the price of the other factor reduces the conditional demand elasticity, summarised in equation (4)

$$
\eta_{11}^{*}=-\sigma s_{2}\left(1-\eta_{w_{2} w_{1}}\right)
$$

The two factor analogue of (3) is $\eta_{11}^{*}=-\sigma s_{2}$ and $\eta_{w_{2} w_{1}}$ is the percentage change in the price of factor $2\left(\mathrm{w}_{2}\right)$ associated with a percentage change in $\mathrm{w}_{1}$. A rise in wages (price of factor 1) will induce firms to substitute from labour into other inputs. To the extent that these are purchased in the domestic economy firms will increase the demand for such inputs and drive up the price, hence limiting the extent of substitution away from labour. Firms who substitute from labour into inputs sourced abroad would not expect the same to be true if a small country has little

\footnotetext{
${ }^{9}$ Moran (2001) provides plenty of case studies between foreign subsidiaries and domestic suppliers and provides evidence of such assistance.

${ }^{10}$ An additional possible explanation is that firms that locate close to an input source do so partly because local inputs are more difficult to substitute for, and that these may often be inputs such as agricultural commodities in food and drink production etc. Think of a foreign owned producer of a food or drink product who would find it difficult to substitute away from labour with a software firm who has skilled labour to some degree at a fixed output level. (Kennedy, 1991) provides evidence that backward linkages in the former industry are much higher than in most other manufacturing industries, including the computer industry.) However, in the econometric analysis below we focus on within firm changes, rather than differences across sectors, hence this explanation is less relevant to our analysis.

${ }^{11}$ See Hicks (1968) Appendix to chapter XI for a formal derivation in the constant returns to scale case, and Hamermesh (1993) for a more general discussion.
} 
impact on the world price of that factor. Hence, their labour demand should be more elastic with respect to the wage rate than that of firms using local inputs.

Fabbri et. al (2003) argue that multinationals may have more elastic demand than domestic firms because firms with global production networks may be able to more easily import intermediate goods that could alternatively be produced by domestic labour. They argue that this is especially likely if a firm is vertically integrated internationally and different plants engage in intra-firm trade. To see how this argument fits into our framework we assume that the multinational subsidiary produces two outputs $y_{1}$ and $y_{2}$ where $y_{2}$ is an intermediate input which can be produced in the subsidiary or imported at a fixed marginal cost from another branch of the company and $y_{1}$ is output of the final good. We assume the firm has two separate production functions for the two goods within the plant for simplicity where $a 1$ is the fraction of the workforce producing the final good and $a 2$ the fraction producing the intermediate good. If we estimate the demand elasticity for the plant holding final output fixed this does not condition on output of the intermediate input. The overall elasticity estimate conditional on final output will be:

$$
\eta_{l l}^{*}=a_{1} \eta_{l l}^{* 1}+\left(1-a_{1}\right) \eta_{l l}^{2}
$$

where $\eta_{l l}^{* 1}$ is the conditional demand elasticity for employment of the final good and $\eta_{l l}^{2}$ is the unconditional demand for the intermediate good which for a given elasticity of substitution may be substantially larger than the conditional elasticity ${ }^{12}$. We might speculate that their conjecture that firms can easily transfer some stages of production

\footnotetext{
${ }^{12}$ Appendix A3 derives the unconditional elasticity for the two factor case and a production function that is homogeneous of degree $\mathrm{r}$. The unconditional elasticity is

$\eta_{11}=-\left[\sigma s_{2}+\frac{s_{1}}{(1-r) r}\right]$ while the two factor analogue of the conditional elasticity is $\eta_{11}^{*}=-\sigma \mathrm{S}_{2}$. While $\mathrm{s}_{\mathrm{i}}$ represents the share of variable costs in one case and output in the other clearly the unconditional elasticity may be much larger.
} 
to another subsidiary for a given final output would be less relevant for firms that purchase a large share of primary inputs locally.

\section{Description of the data}

The preceding discussion illustrates that there are plausible reasons why one might expect the source of inputs to matter for foreign firms' labour demand elasticities. We now turn to examining this issue empirically. The data for our analysis are taken from the Irish Economy Expenditure Survey (IEE), undertaken annually by Forfas, the government agency with responsibility for enterprise development, science and technology. This is an annual survey of plants in Irish manufacturing with at least 20 employees, although a plant, once it is included, is generally still surveyed even if its employment level falls below the 20 employee cutoff point.

The survey provides plant level information on, inter alia, output, employment, nationality of ownership, as well as details on plants' expenditure on labour and other inputs. ${ }^{13}$ The response rate to this survey is generally estimated to be between 60 and 80 per cent of the targeted plant population. The data cover the period 1983-1998 and provide an unbalanced panel for 2,675 plants. A look at the data shows that total exits over this period in our data only account for 3.3 percent of total plants.

Nationality of ownership is covered as a dichotomous variable indicating whether a plant is foreign or domestic owned. In this context one should note that Forfás defines foreign plants as plants that are majority-owned by foreign shareholders, i.e., where there is at least 50 per cent foreign ownership. While,

\footnotetext{
${ }^{13}$ Note that the dataset does not allow us to distinguish skill groups for workers, thus we treat labour as homogeneous.
} 
arguably, plants with lower foreign ownership should still possibly considered to be foreign owned, this is not necessarily a problem for the case of Ireland since almost all inward foreign direct investment has been greenfield investment rather than acquisition of local firms (see Barry and Bradley, 1997). By way of summary statistics, Figure 1 shows the development of total employment in foreign and domestic plants in Irish manufacturing over the sample period. One should note that employment in foreign-owned plants has increased more rapidly than domestic employment, with a growth from around 58,000 to almost 100,000 employees in 1998.

\section{[Figure 1 here]}

The IEE survey also includes information on plants' expenditure on intermediate inputs and breaks this down into domestically sourced and imported intermediates and we use this information to calculate our measure of local sourcing. More precisely, we calculate a linkage indicator as the percentage of inputs sourced locally (see, e.g., Görg and Ruane, 2000; Kennedy, 1991; Cohen, 1973). Table 1 shows the development of total backward linkages in 1983 and 1998 respectively by NACE 2 digit industry.

\section{[Table 1 here]}

One should note, firstly, that foreign-owned plants on average have lower linkages than domestic plants, although there are some of exceptions (e.g., 19 leather, in 1998). Moreover, the table highlights sectoral differences with the highest linkages occurring for domestic plants in sectors 30 (computers \& office machinery) in 1983 and 15 (food \& beverages) in 1998, and for foreign plants in sectors 27 (basic metals) in 1983 and 19 (leather) in 1998. As expected, there are significant differences in linkages between foreign and domestic plants, most noteworthy perhaps 
in sector 30 (office machinery) in 1983, although this difference has all but disappeared in 1998. The table also shows that for multinationals, backward linkages have generally increased over the 1983 to 1998 period. This may at least in part reflect the emphasis of the National Linkage Programme in Ireland on creating linkages between foreign multinationals and local suppliers (Ruane, 2001).

\section{Estimating labour demand elasticities}

\subsection{Differences between foreign and domestic plants}

The first step in our empirical analysis is to establish whether in our dataset there are differences in labour demand elasticities between domestic and foreign owned plants. In order to do so we specify the following dynamic conditional labour demand function for plant $i$ in year $t$,

$$
\begin{aligned}
& l_{i t}=\alpha_{1} l_{i t-s}+\alpha_{2} w_{i t}+\alpha_{3} y_{i t} \\
& +\beta_{1} \text { foreign }_{i t}+\beta_{2}\left(w^{*} \text { foreign }\right)_{i t}+\beta_{3}\left(y^{*} \text { foreign }_{i t}+d_{t}+d_{i}+e_{i t}\right.
\end{aligned}
$$

where $l, w$, and $y$ are logged values of employment, wages per head, and output, respectively. The variables $d_{t}, d_{i}$, and $e$ are time specific effects, plant specific time invariant effects, and an i.i.d. error term, respectively; all unobservable to the econometrician. ${ }^{14}$ Depending on observations per plant one may want to include up to t-s lagged dependent variable in the equation, since, arguably, labour demand may be dynamic in nature because of a non-smooth adjustment process in plants' employment policy (see, for example, Hamermesh, 1993). foreign in (6) is a dummy variable equal to one if a plant is foreign-owned and zero otherwise. This variable is

\footnotetext{
${ }^{14}$ A static version of the equation including only $w$ and $y$ can be derived from a Cobb-Douglas production function using labour and capital as inputs. The cost of capital is difficult to measure at the plant level. We assume that the cost of capital is the same for all plants in the economy and is, hence, captured by time dummies.
} 
interacted with $w$ and $y$ to allow for nationality of ownership differences in the wage and output elasticity.

In terms of estimation of equation (6) one should note that simply using OLS is likely to prove problematic. Specifically, employment is likely to be simultaneously determined with output and may also affect plant level wages if the plant is not a price taker in the local labour market. Also, the wage variable may not only capture labour costs but may also be a measure of firms' skill intensities. This is because a firm that uses higher skilled workers must pay higher average wages due to a composition effect, leading to another potential source of endogeneity in the estimation.

If such endogeneity biases were time invariant then simply first differencing the data would provide a possible solution. However, given the length of the panel of individual plants (up to 15 years) this is unlikely to be the case. ${ }^{15}$ One possible way of solving this problem would be to first difference equation (6) and apply a first differenced generalized methods of moments (GMM) estimator as developed by Arellano and Bond (1991). This estimator uses suitably lagged levels of the endogenous variables as instruments in the first differenced equation. However, this approach has been criticised recently since it has been argued that lagged levels of variables may only be weak instruments for the variables in first differences. In order to overcome this problem of weak instruments, while also controlling for plant specific fixed effects, Blundell and Bond (1998) suggest using a system GMM estimator which uses an additional set of moment restrictions to improve estimation. ${ }^{16}$

\footnotetext{
${ }^{15}$ The inclusion of the lagged dependent variable would render a simple fixed estimator inappropriate in this context. In a transformation from the mean, the difference between the lagged dependent variable and its mean $\left(l_{i t-1}-\bar{l}_{i}\right)$ is by construction correlated with $e_{i t}-\bar{e}_{i}$, as the mean $\bar{e}_{i}$ contains $e_{i t-1}$, which is correlated with $l_{i t-1}$. See, for example, Baltagi (1995) for a discussion.

${ }^{16}$ The appendix provides an illustration of the "weak instrument" problem in first differenced GMM. As far as we are aware there is no formal test for weak instruments in the context of dynamic panel
} 
Accordingly, the estimator uses a stacked system of first differenced and level versions of the estimating equation, where for the former appropriately lagged values and for the latter appropriately lagged differences of the endogenous variables can serve as valid instruments. The validity of these instruments can be tested using a Hansen J test. The consistency of our estimates also rests on the assumption that there is no second order correlation of the residuals of the first-differenced equation. The standard procedure to verify this is to use an $\mathrm{AR}(2)$ test on the residuals developed by Arellano and Bond (1991).

The results of estimating equation (6) are reported in Table 2. Column (1) provides the simplest model using only one lag of the dependent variable. As the Hansen statistic indicates, we reject the hypothesis of instrument validity. Also, we reject the hypothesis of no second order autocorrelation (AR(2)). Hence, this equation is clearly misspecified. Column (2) adds the second lag of the dependent variable which improves on autocorrelation, but still leaves us with an instrument set that is not valid. Only in column (3) have we got a specification that has valid instruments where we can also reject the hypothesis of no $\operatorname{AR}(2)$ and we hence use this as our benchmark specification.

Turning to the coefficients, we find from column (3) that the wage and output elasticities look economically sensible - they are negative and positive, respectively, and statistically significant in both cases. The point estimates are also well within the range of those generally found in the literature (e.g., Barba Navaretti et al., 2003). More importantly, the significant coefficients on the interaction terms suggest that

GMM and we hence follow an approach used by Bond et al. (2001). Estimating a first differenced version of equation (7) using OLS would upward bias coefficients on the lagged dependent variable, while a fixed effects (FE) transformation would lead to a downward bias. As the table in the appendix shows, using first differenced GMM a la Arellano and Bond (1991) produces coefficients on $\mathrm{I}_{\mathrm{t}-1}$ that are close to the FE model. This suggests that the first differenced GMM model is biased downwards which can be due to weak instruments (Bond et al., 2001). The estimates produced by the system GMM estimator lie comfortably between OLS and FE estimates suggesting that it is more reliable. 
multinationals respond differently to wage changes in terms of their demand for labour. Specifically, the wage elasticity for multinationals is higher (in absolute terms) than for domestic plants; a result found by Barba Navaretti et al. (2003) for Finland and Sweden. We do not find any statistically significant differences in the output elasticities, however. Overall, the results thus far suggest that it is more reasonable to estimate the effect of linkages on elasticities separately for domestic and foreign plants.

[Table 2 here]

\subsection{Linkages and labour demand}

If multinationals have higher labour demand elasticities than domestic firms it may indeed be the case that they are more likely to reduce labour demand than comparable domestic plants if labour costs increase. The issue now becomes whether further integration of multinationals through local linkages may provide a counter force to this, and as discussed in Section 2, there may be reasons to think that it does. In order to investigate this issue we examine whether labour demand elasticities depend on the degree to which multinationals are integrated into the local economy. More specifically, we estimate a dynamic conditional labour demand function, similar to equation (7) as

$$
l_{i t}=\gamma_{1} l_{i t-s}+\gamma_{2} w_{i t}+\gamma_{3} y_{i t}+\lambda_{1} \operatorname{link}_{i t}+\lambda_{2}(\operatorname{link} * w)_{i t}+\lambda_{3}(\operatorname{link} * y)_{i t}+d_{t}+d_{i}+e_{i t}
$$

where link is the measure of local linkages which is interacted with $w$ and $y$. Hence, $\gamma_{2}+\lambda_{2}(\text { link })_{i t}$ represents the wage elasticity of labour demand, which by construction depends on the degree of local linkages. The crucial point of the analysis is, hence, whether $\lambda_{2}$ is statistically significantly different from zero, and whether it is 
different for multinationals and domestic firms. We check for the latter by including appropriate triple interaction terms.

Table 3 shows the results of estimating equation (7). Column (1) reports elasticities based on the full sample of plants, not distinguishing between foreign and domestic owned establishments. The results indicate that there is indeed a statistically significant impact of linkages on the wage elasticity of labour demand for all firms. However, allowing for different effects of linkages for domestic and foreign firms reveals some interesting differences across nationality of ownership. To do so we construct a triple interaction term of $(w *$ link $*$ foreign) while also including the interaction of $(w *$ foreign $)$ as in Table 2 . The latter interaction term thus allows for differences in wage elasticities for foreign firms, while the former allows for a different effect of linkages on the wage elasticity for foreign firms.

The results in column (2) show that linkages have a statistically significant and positive effect on the wage elasticity for all firms (as apparent from the interaction of log wage * linkage). However, we also find from the triple interaction term (log wage * linkage * foreign) that the positive effect is higher for foreign firms at $(0.058+$ $0.023=$ ) 0.081 than for domestic firms at 0.058 . The difference in results could perhaps reflect the fact that domestic plants source different types of inputs locally, which may be easily substitutable for local labour, hence there may be less effect of increased linkages on the elasticity. ${ }^{17}$

Using the point estimates in column (2) implies that the wage elasticity of labour demand for a foreign owned plant with zero linkages is $(0.217+0.107=)$ 0.324, whereas a foreign plant with a mean level of local linkages has a wage elasticity of 0.289 . Increasing the degree of linkages by two standard deviations from

\footnotetext{
${ }^{17}$ Unfortunately our dataset does not distinguish different types of inputs, hence we cannot follow up this conjecture with further analysis.
} 
the mean then implies a further reduction in the elasticity to 0.248. Hence, the estimated coefficients are not only statistically, but also economically, significant. ${ }^{18}$ One may want to notice also that even if a foreign plant had a linkage coefficient of 1 its wage elasticity would still be substantially higher (at 0.243 ) than that of a domestic plant with zero linkages (at 0.217). Hence, while linkages may help to reduce the elasticity they are not enough to explain away the higher elasticities in foreign than in domestic plants. $^{19}$

[Table 3 here]

\section{Robustness checks}

One possible concern with the estimation above is that labour demand elasticities may depend on size of the plant (Hamermesh and Pfann, 1996) and our results may therefore just reflect the fact that multinationals are generally larger than domestic plants, and that larger firms have higher linkages (as found by Görg and Ruane, 2001 and Alfaro and Rodriguez-Clare, 2004). We, therefore, provide a robustness check to deal with the issue of plant size. Specifically, we classify plants into three size categories according to their average size over the sample period: small (employment less than $33^{\text {rd }}$ percentile of the size distribution), medium (employment between $33^{\text {rd }}$ and $66^{\text {th }}$ percentile of the size distribution), and large (employment greater than $66^{\text {th }}$ percentile of the size distribution) and estimate equation (8) on these different samples separately.

Columns (4) to (6) in Table 3 present these results. Our findings on the effect of linkages for multinationals still hold. While we indeed find that wage elasticities

\footnotetext{
${ }^{18}$ In 1998, the mean ratio of locally sourced inputs over total inputs for foreign owned plants is 0.42 (see Table 1), the standard deviation is 0.25 .

${ }^{19}$ Column (3) presents an alternative regression which only uses one lag of the dependent variable. However, as in Table 2, this specification is mis-specified and we reject the hypothesis of no second order autocorrelation.
} 
differ by size class we also find that for all size groups, increased linkages are associated with reductions in these elasticities for foreign firms, although the coefficient on the triple interaction term is, while still positive, statistically insignificant for large firms in column (6). Hence, our previous findings are not just reflections of the fact that we do not take into account size differences in the estimation of wage elasticities.

Another robustness check considers the unbalanced nature of our panel data which contains exit, so that if the probability of exit were correlated with the degree of local linkages and employment then our results may be biased. For example, foreign multinationals may have more sunk costs the more integrated they are into the local economy and hence may be less likely to exit. However, exiting plants are also likely to adjust their employment differently prior to exit. As argued in Section 3, there is very little exit in our data and, hence, it may be considered negligible in our analysis. Regardless, we report some additional specifications to ensure that are our results are not biased due to plant exit. In this regard, Column (1) of Table 4 reports a regression on the sample of surviving plants only, thus excluding exitors, while column (2) includes a dummy equal to 1 for the whole lifetime of a plant that exits the data, and interacts this dummy with all variables containing log wage and its interaction terms.

Note from column (1) that the results on the survivor sample is similar to that reported in column (2) of Table 3. Considering column (2), while we find that the dummy variable and interaction terms are all statistically significant (except the final four way interaction of wage, linkage, foreign and exit dummy), we also find that the positive and statistically significant coefficient on the triple interaction of linkage and wages for foreign-owned plants is robust to this specification. Hence, our result that 
higher local linkages decrease wage elasticities of labour demand is robust to the different ways of dealing with the potential bias introduced through plants exiting the dataset.

\section{[Table 4 here]}

\section{Conclusions}

This paper investigates the link between nationality of ownership and labour demand elasticities at the level of the plant. In particular, we examine whether labour demand in multinationals (or other domestic firms) becomes less elastic if a plant has backward linkages with the local economy, proposing the possibility that locally purchased inputs may be more difficult to substitute for labour than other inputs, due to the very nature of the inputs. Our evidence shows that the extent of local linkages indeed reduces the wage elasticity of labour demand for foreign owned plants. In robustness checks we find that the results hold when allowing for plant heterogeneity in terms of size and when taking account of exit.

While our labour demand estimations show that increasing the level of linkages may lead to economically significant reductions in foreign plants' wage elasticities, it is also clear that even if a multinational sourced all of its inputs in Ireland it would still have a substantially higher elasticity than a comparable domestic plant. Hence, while linkages are important in explaining differences in elasticities they are not sufficient to explain away the fact that foreign plants have higher wage elasticities than domestic plants. 


\section{References}

Allen, R,G,D. (1969) Mathematical Analysis for Economists, MacMillan St. Martins Press

Alfaro, Laura and Andres Rodríguez-Claré (2004), Multinationals and linkages: An empirical investigation, Economia, Spring 2004, 113-169.

Arellano, Manuel and Stephen Bond (1991), Some Tests of Specification for Panel Data: Monte Carlo Evidence and an Application to Employment Equations, Review of Economic Studies, 58, 277-297.

Baltagi, B.H. (1995) Econometric Analysis of Panel Data, Chichester, Wiley \& Sons.

Barba Navaretti, Giorgio, Daniele Checchi and Alessandro Turrini (2003), Adjusting Labor Demand: Multinational Versus National Firms: A Cross-European Analysis, Journal of the European Economic Association, April-May, pp. 708-719

Bernard, Andrew B. and Fredrik Sjöholm (2003), Foreign owners and plant survival, NBER Working Paper 10039.

Blundell, Richard and Stephen Bond (1998), Initial Conditions and Moment Restrictions in Dynamic Panel Data Models, Journal of Econometrics, 87, 115-137.

Cohen, B. (1973), Comparative behaviour of foreign and domestic export firms in a developing economy, Review of Economics and Statistics, 55, 190-197.

Driffield, Nigel, Max Munday, and Annette Roberts. 2002. "Foreign Direct Investment, Transactions Linkages, and the Performance of the Domestic Sector." International Journal of the Economics of Business 9(3): 335-51.

Fabbri, Francesca, Jonathan E. Haskel and Matthew J. Slaughter (2003), Does Nationality of Ownership Matter for Labor Demand?, Journal of the European Economic Association, April-May, pp698-707

Girma, Sourafel and Holger Görg (2007), Evaluating the foreign ownership wage premium using a difference-in-differences matching approach, Journal of International Economics, forthcoming.

Görg, Holger, Michael Henry, Eric Strobl and Frank Walsh (2006), Multinational companies, backward linkages and labour demand elasticities, GEP Research Paper, University of Nottingham

Görg, Holger and Eric Strobl (2003), Footloose multinationals?, The Manchester School. 71: 1-19.

Görg, Holger and Frances Ruane (2000), An analysis of backward linkages in the Irish electronics sector, Economic and Social Review, 31, 215-235.

Hamermesh, Daniel S. (1993) Labor Demand, Princeton University Press

Hamermesh, Daniel S. and Gerard Pfann (1996), Adjustment costs in factor demand, Journal of Economic Literature, 34, 1264-1292.

Hicks, J.R. (1968) The Theory of Wages, MacMillan, second edition.

Javorcik, Beata Smarzynska (2004), Does Foreign Direct Investment Increase the Productivity of Domestic Firms? In Search of Spillovers through Backward Linkages, American Economic Review, 94, 605-627. 
Kennedy, Kieran A. (1991), Linkages and overseas industry, in: Foley, A. and D. McAleese (eds.), Overseas industry in Ireland, Dublin: Gill and Macmillan, pp. 82105.

Konings, Jozef and Alan Murphy (2001), Do Multinational Enterprises Substitute Parent Jobs for foreign Ones? Evidence from Firm Level panel data, CEPR Discussion Paper 2972.

Lipsey, R.E. and Sjöholm, F. (2004). 'Foreign direct investment, education and wages in Indonesian manufacturing', Journal of Development Economics, Vol. 73, pp. 415422.

Markusen, James R. (2002) Multinational Firms and the Theory of International Trade, MIT Press

Moran, Theodore H. (2001), Parental Supervision: The New Paradigm for Foreign Direct Investment and Development, Washington DC: Institute for International Economics.

Mosak, Jacob, L. (1938), Interrelations of Production, Price, and Derived Demand, Journal of Political Economy, Vol. 46, No. 6. pp761-787

OECD (1997), Jobs outlook, OECD: Paris.

Ruane, Frances (2001), Reflections on linkage policy in Irish manufacturing - policy chasing a moving target?, mimeo, available at www.unece.org/ead/misc/ffd2001/ruane.doc

Rodrik, Dani (1997) Has globalization gone too far? Washington, DC: Institute for International Economics

Scheve, Kenneth and Matthew J. Slaughter (2004), Economic insecurity and the globalization of production, American Journal of Political Science, 48, 662-674

Slaughter, Matthew J. (2001), International Trade and Labor-Demand Elasticities, Journal of International Economics, 54, 27-56

United Nations (2004), World Investment Report 2004, UN: Geneva and New York. 


\section{Appendix I: Theory}

A1: Deriving the conditional labour demand elasticity

A price taking firm firm has a production function with $n$ inputs:

$y=f\left(x_{1}, \ldots x_{n}\right)$

The Lagrangian function for cost minimisation is:

$\ell=w_{1} x_{1}+w_{2} x_{2} . .+w_{n} x_{n}+\lambda\left[y-f\left(x_{1} . . x_{n}\right)\right]$

For each of the $\mathrm{n}$ factors we get a first order condition:

$w_{i}=\lambda f_{i}\left(x_{1}, . . x_{n}\right)$

Differentiating the production function and the $\mathrm{n}$ first order conditions with respect to $\lambda, \mathrm{w}_{1}$ and all the inputs we get the following system of equations:

$$
\begin{aligned}
& d y=f_{1} d x_{1}+f_{2} d x_{2} . . f_{n} d x_{n}=0 \\
& f_{1} d \lambda+\lambda f_{11} d x_{1} . . \lambda f_{1 n} d x_{n}=d w_{1}
\end{aligned}
$$

fnd $\lambda+\lambda f_{n 1} d x_{1} \ldots \lambda f_{n n} d x_{n}=0$

This can be represented in matrix format as:

$\left[\begin{array}{cccc}0 & f_{1} & . . & f_{n} \\ f_{1} & f_{11} & . . & f_{1 n} \\ \cdot & . . & . . & . . \\ f_{n} & f_{n 1} & . . & f_{n n}\end{array}\right]\left[\begin{array}{c}\frac{d \lambda}{d w_{1} \lambda} \\ \frac{d x_{1}}{d w_{1}} \\ \frac{d x_{n}}{d w_{n}}\end{array}\right]=\left[\begin{array}{c}0 \\ \frac{1}{\lambda} \\ 0 \\ 0\end{array}\right]$

Applying Cramers rule where $\mathrm{B}$ is the Bordered Hessian above and $\mathrm{B}_{22}$ replaces the second column with the solution vector, we get:

$$
\frac{\partial x_{1}}{\partial w_{1}}=\frac{\left|B_{22}\right|}{\lambda|B|}
$$


Allen (1969) derives the following expression for the elasticity of substitution:

$\sigma_{i j}=\frac{\left(f_{1} x_{n} . .+f_{2} x_{n}\right)}{x_{i} x_{j}} \frac{\left|B_{i j}\right|}{|B|}$

Using this definition of the elasticity of substitution ${ }^{20}$ in (A5) along with the first order condition we get the labour demand elasticity conditional on output:

$\eta_{11}^{*}=\frac{\partial x_{1}}{\partial w_{1}} \frac{w_{1}}{x_{1}}=\frac{\sum_{j \neq 1}^{n} \sigma_{1 j} f_{j} x_{j}}{\sum_{i=1}^{n} f_{i} x_{i}}=\sum_{j=1}^{n} \sigma_{1 j} s_{j}$

A2: Upward sloping supply for other factors

We will assume there are only two factor in this case. The elasticity of substitution in this case can is:

$\sigma_{12}=\frac{-f_{1} f_{2}\left(x_{1} f_{1}+x_{2} f_{2}\right)}{x_{1} x_{2}\left(f_{1}^{2} f_{22}+f_{2}^{2} f_{11}-2 f_{1} f_{2} f_{21}\right)}$

The cost minimisation problem can be represented as above in matrix format except that we allow $w_{2}$ to vary as well as $w_{1}$. That is we assume an exogenous change in the wage leads to an increase in demand and the wage of the other factor if its supply curve slopes upwards:

$\left[\begin{array}{ccc}0 & f_{1} & f_{2} \\ f_{1} & f_{11} & f_{12} \\ f_{2} & f_{21} & f_{22}\end{array}\right]\left[\begin{array}{c}\frac{d \lambda}{d w_{1} \lambda} \\ \frac{d x_{1}}{d w_{1}} \\ \frac{d x_{2}}{d w_{1}}\end{array}\right]=\left[\begin{array}{c}0 \\ \frac{1}{\lambda} \\ \frac{d w_{1}}{d w_{2} \lambda}\end{array}\right]$

Using (A4) to get the solution and noting from (A7) that:

$\frac{\partial x_{1}}{\partial w_{1}}=\frac{\left|B_{22}\right|}{\lambda|B|}=\frac{f_{2} f_{1} d w_{2} / d w_{1}-f_{2}^{2}}{\lambda|B|}$

${ }^{20}$ Using this definition $\sigma_{11}=\frac{\left(f_{1} x_{n} . .+f_{2} x_{n}\right)}{x_{1}^{2}} \frac{\left|B_{22}\right|}{|B|}$ where $\mathrm{B}_{22}$ is the determinant of the cofactor of the bordered Hessian for the second of the $\mathrm{n}+1$ rows and columns. Also note from Allen (1969) p504 that $-\sigma_{11} \frac{f_{1} x_{1}}{\sum_{i=1}^{n} f_{i} x_{i}}=\sum_{i=2}^{n} \sigma_{1 i} \frac{f_{i} x_{i}}{\sum_{i=1}^{n} f_{i} x_{i}}$ 
Also note in the two factor case from (A7) that:

$|B|=\frac{\sigma_{12} x_{1} x_{2}}{f_{1} f_{2}\left(f_{1} x_{1}+f_{2} x_{2}\right)}$

From (A7) and (A8) we get:

$\eta_{11}^{*}=-\sigma_{2}\left(1-\eta_{w_{2} w_{1}}\right)$

\section{A3: The unconditionat elasticity}

Next we look for the labour demand elasticity when output varies after an increase in the price of labour. We assume that the price of output is fixed. Mosak (1938) analyses the impact of a change in prices on factor and output demands for price taking firms. Mosaks approach is more detailed and would allow us to calculate the substitution and scale effects separately. For simplicity we assume that the production function is homogeneous of degree $r$ where $r$ is less than unity. We will assume that fixed costs ensure an optimal size at a positive level of output for the firm. The firm will maximise profits:

$$
p f\left(x_{1}, x_{2}\right)-w_{1} x_{1}-w_{2} x_{2}-F
$$

The first order conditions are as in (A3) except lambda is now the output price p.

Differentiating the first order conditions with respect to $\mathrm{x}_{1}, \mathrm{x}_{2}$ and $\mathrm{w}_{1}$ and solving we get the change in labour from a change in the wage:

$\frac{d x_{1}}{d w_{1}}=\frac{f_{22}}{p\left(f_{11} f_{22}-f_{12}^{2}\right)}$

Our assumption that the production function is homogeneous of degree $r$ implies the following:

$$
\begin{aligned}
& r y=f_{1} x_{1}+f_{1} x_{2} \\
& f_{11}=(r-1) \frac{f_{1}}{x_{1}}-f_{12} \frac{x_{2}}{x_{1}} \\
& f_{22}=(r-1) \frac{f_{2}}{x_{2}}-f_{12} \frac{x_{1}}{x_{2}}
\end{aligned}
$$

Substituting A9-11 into (A5) the elasticity of substitution simplifies to to:

$$
\sigma_{12}=\frac{f_{1} f_{2}}{(1-r) f_{1} f_{2}+r f_{12} y}
$$


Substituting A9-11 into (A10) we get:

$\frac{d x_{1}}{d w_{1}}=-\frac{x_{1}\left[(1-r) f_{2}+f_{12} x_{1}\right]}{p(1-r)\left[(1-r) f_{1} f_{2}+f_{12} r y\right]}$

Using (A.14) in the denominator and again applying the first order condition, the own price elasticity of demand for factor 1 at fixed output price is:

$\eta_{11}=\frac{d x_{1}}{d w_{1}} \frac{w_{1}}{x_{1}}=-\sigma\left(1+f_{21} \frac{x_{1}}{f_{2}(1-r)}\right)$

Note (A14) can be rearranged as: $\frac{r y f_{12}}{f_{1} f_{2}}=\frac{1}{\sigma_{12}}-(1-r)$. Using this in (A16) when $s_{i}=\frac{f_{i} x_{i}}{y}$ we get:

$\eta_{11}=-\left[\sigma s_{2}+\frac{s_{1}}{(1-r) r}\right] \quad(\mathrm{A} 17)$ 
Table 1: Development of backward linkages

(locally sourced inputs divided by total inputs)

\begin{tabular}{|c|c|c|c|c|c|}
\hline & & 1983 & & 1998 & \\
\hline NACE & Description & domestic & foreign & domestic & foreign \\
\hline 15 & Food \& beverages & 0.77 & 0.67 & 0.80 & 0.69 \\
\hline 16 & Tobacco & 0.47 & 0.32 & 0.38 & 0.64 \\
\hline 17 & Textiles & 0.26 & 0.33 & 0.37 & 0.30 \\
\hline 18 & Wearing apparel & 0.21 & 0.27 & 0.40 & 0.41 \\
\hline 19 & Leather & 0.51 & 0.34 & 0.56 & 0.72 \\
\hline 20 & Wood \& wood products & 0.47 & & 0.53 & 0.61 \\
\hline 21 & Pulp \& paper & 0.42 & 0.29 & 0.50 & 0.33 \\
\hline 22 & Publishing \& printing & 0.25 & 0.32 & 0.55 & 0.48 \\
\hline 23 & Petroleum & 0.48 & & 0.31 & 0.22 \\
\hline 24 & Chemicals & 0.44 & 0.35 & 0.57 & 0.39 \\
\hline 25 & Rubber \& plastics & 0.33 & 0.27 & 0.46 & 0.37 \\
\hline 26 & Non metallic minerals & 0.48 & 0.38 & 0.69 & 0.51 \\
\hline 27 & Basic metals & 0.63 & 0.90 & 0.57 & 0.30 \\
\hline 28 & Fabricated metals & 0.31 & 0.27 & 0.49 & 0.38 \\
\hline 29 & Machinery \& equipment & 0.46 & 0.33 & 0.48 & 0.37 \\
\hline 30 & Computers \& Office machinery & 0.92 & 0.23 & 0.46 & 0.39 \\
\hline 31 & Electrical machinery & 0.31 & 0.35 & 0.49 & 0.34 \\
\hline 32 & TV and telephone & 0.26 & 0.19 & 0.47 & 0.34 \\
\hline 33 & Medical \& optical instruments & 0.33 & 0.33 & 0.59 & 0.41 \\
\hline 34 & Motor vehicles & 0.27 & 0.31 & 0.40 & 0.46 \\
\hline 35 & Other transport equipment & 0.24 & 0.09 & 0.28 & 0.45 \\
\hline \multirow[t]{2}{*}{36} & Not elsewhere classified & 0.40 & 0.60 & 0.51 & 0.53 \\
\hline & Total & 0.48 & 0.36 & 0.56 & 0.42 \\
\hline
\end{tabular}

Source: own calculations from Irish Expenditure Survey 
Table 2: Labour demand elasticities, foreign vs domestic

\begin{tabular}{|l|l|l|l|}
\hline & $(1)$ & $(2)$ & $(3)$ \\
\hline $\log$ employment (t-1) & 0.459 & 0.561 & 0.916 \\
\hline log employment (t-2) & $(0.006)^{\mathrm{a}}$ & $(0.007)^{\mathrm{a}}$ & $(0.007)^{\mathrm{a}}$ \\
\hline & & -0.014 & -0.073 \\
\hline $\log$ wage & & $(0.003)^{\mathrm{a}}$ & $(0.003)^{\mathrm{a}}$ \\
\hline & -0.518 & -0.449 & -0.435 \\
\hline $\log$ output & $(0.015)^{\mathrm{a}}$ & $(0.014)^{\mathrm{a}}$ & $(0.010)^{\mathrm{a}}$ \\
\hline & 0.489 & 0.422 & 0.457 \\
\hline $\log$ wage (t-1) & $(0.010)^{\mathrm{a}}$ & $(0.008)^{\mathrm{a}}$ & $(0.006)^{\mathrm{a}}$ \\
\hline & & & 0.334 \\
\hline $\log$ output (t-1) & & & $(0.007)^{\mathrm{a}}$ \\
\hline & & & -0.322 \\
\hline foreign dummy & & & $(0.005)^{\mathrm{a}}$ \\
\hline & 0.957 & 0.604 & 0.214 \\
\hline $\log$ output * foreign dummy & $(0.071)^{\mathrm{a}}$ & $(0.061)^{\mathrm{a}}$ & $(0.038)^{\mathrm{a}}$ \\
\hline & -0.131 & -0.056 & -0.008 \\
\hline log wage * foreign dummy & $(0.011)^{\mathrm{a}}$ & $(0.009)^{\mathrm{a}}$ & $(0.006)$ \\
\hline & 0.081 & -0.039 & -0.055 \\
\hline Hansen test (p-value) & $(0.015)^{\mathrm{a}}$ & $(0.015)^{\mathrm{a}}$ & $(0.008)^{\mathrm{a}}$ \\
\hline AR(2) test (p-value) & 0.00 & 0.00 & 0.10 \\
\hline Observations & 0.00 & 0.08 & 0.69 \\
\hline & 12474 & 9717 & 9717 \\
\hline
\end{tabular}

System GMM estimation

Dependent variable: $\log ($ employment)

Standard errors in parentheses

${ }^{\mathrm{c}}$ significant at $10 \%$; ${ }^{\mathrm{b}}$ significant at $5 \%$; ${ }^{\mathrm{a}}$ significant at $1 \%$ 
Table 3: Conditional labour demand including backward linkages

\begin{tabular}{|c|c|c|c|c|c|c|}
\hline & (1) & (2) & (3) & (4) & (5) & (6) \\
\hline & all firms & all firms & all firms & $\begin{array}{l}\text { small } \\
\text { firms }\end{array}$ & $\begin{array}{l}\text { medium } \\
\text { firms }\end{array}$ & large firms \\
\hline \multirow{2}{*}{$\begin{array}{l}\text { log employment (t- } \\
\text { 1) }\end{array}$} & 0.843 & 0.836 & 0.683 & 0.769 & 0.828 & 0.875 \\
\hline & $(0.009)^{\mathrm{a}}$ & $(0.003)^{\mathrm{a}}$ & $(0.002)^{\mathrm{a}}$ & $(0.002)^{\mathrm{a}}$ & $(0.001)^{\mathrm{a}}$ & $(0.002)^{\mathrm{a}}$ \\
\hline \multirow{2}{*}{$\begin{array}{l}\text { log employment (t- } \\
\text { 2) }\end{array}$} & -0.069 & -0.074 & & -0.086 & -0.111 & -0.104 \\
\hline & $(0.005)^{\mathrm{a}}$ & $(0.001)^{\mathrm{a}}$ & & $(0.001)^{\mathrm{a}}$ & $(0.001)^{\mathrm{a}}$ & $(0.001)^{\mathrm{a}}$ \\
\hline \multirow[t]{2}{*}{ log wage } & -0.240 & -0.217 & -0.268 & -0.193 & -0.208 & -0.312 \\
\hline & $(0.015)^{\mathrm{a}}$ & $(0.008)^{\mathrm{a}}$ & $(0.009)^{\mathrm{a}}$ & $(0.003)^{\mathrm{a}}$ & $(0.002)^{\mathrm{a}}$ & $(0.004)^{\mathrm{a}}$ \\
\hline \multirow{2}{*}{ log output } & 0.214 & 0.212 & 0.273 & 0.192 & 0.193 & 0.219 \\
\hline & $(0.008)^{\mathrm{a}}$ & $(0.004)^{\mathrm{a}}$ & $(0.005)^{\mathrm{a}}$ & $(0.002)^{\mathrm{a}}$ & $(0.001)^{\mathrm{a}}$ & $(0.002)^{\mathrm{a}}$ \\
\hline \multirow[t]{2}{*}{ linkage } & 0.342 & 0.336 & 0.372 & 0.345 & 0.446 & 0.398 \\
\hline & $(0.077)^{\mathrm{a}}$ & $(0.025)^{\mathrm{a}}$ & $(0.025)^{\mathrm{a}}$ & $(0.020)^{\mathrm{a}}$ & $(0.007)^{\mathrm{a}}$ & $(0.012)^{\mathrm{a}}$ \\
\hline \multirow[t]{2}{*}{ log wage * linkage } & 0.074 & 0.058 & 0.008 & 0.115 & 0.002 & 0.094 \\
\hline & $(0.021)^{\mathrm{a}}$ & $(0.012)^{\mathrm{a}}$ & $(0.012)$ & $(0.005)^{\mathrm{a}}$ & $(0.003)$ & $(0.005)^{\mathrm{a}}$ \\
\hline \multirow{2}{*}{$\begin{array}{l}\text { log output * } \\
\text { linkage }\end{array}$} & -0.069 & -0.071 & -0.064 & -0.089 & -0.071 & -0.088 \\
\hline & $(0.012)^{\mathrm{a}}$ & $(0.005)^{\mathrm{a}}$ & $(0.005)^{\mathrm{a}}$ & $(0.003)^{\mathrm{a}}$ & $(0.001)^{\mathrm{a}}$ & $(0.002)^{\mathrm{a}}$ \\
\hline \multirow[t]{2}{*}{ foreign dummy } & & 0.118 & 0.186 & 0.722 & 0.253 & 0.182 \\
\hline & & $(0.017)^{\mathrm{a}}$ & $(0.025)^{\mathrm{a}}$ & $(0.008)^{\mathrm{a}}$ & $(0.005)^{\mathrm{a}}$ & $(0.010)^{\mathrm{a}}$ \\
\hline \multirow[t]{2}{*}{ log wage * foreign } & & -0.107 & -0.135 & -0.403 & -0.022 & 0.022 \\
\hline & & $(0.008)^{\mathrm{a}}$ & $(0.009)^{\mathrm{a}}$ & $(0.005)^{\mathrm{a}}$ & $(0.003)^{\mathrm{a}}$ & $(0.004)^{\mathrm{a}}$ \\
\hline \multirow[t]{2}{*}{$\begin{array}{l}\text { log output * } \\
\text { foreign }\end{array}$} & & 0.009 & 0.010 & 0.037 & -0.030 & -0.038 \\
\hline & & $(0.004)^{\mathrm{a}}$ & $(0.005)^{b}$ & $(0.002)^{\mathrm{a}}$ & $(0.001)^{\mathrm{a}}$ & $(0.002)^{\mathrm{a}}$ \\
\hline \multirow{2}{*}{$\begin{array}{l}\text { log wage * linkage } \\
* \text { foreign } \\
\end{array}$} & & 0.023 & 0.069 & 0.518 & 0.014 & 0.007 \\
\hline & & $(0.014)^{*}$ & $(0.014)^{\mathrm{a}}$ & $(0.010)^{\mathrm{a}}$ & $(0.005)^{\mathrm{a}}$ & $(0.006)$ \\
\hline \multirow{2}{*}{$\begin{array}{l}\text { log output } * \\
\text { linkage * foreign }\end{array}$} & & 0.018 & 0.006 & -0.163 & 0.007 & 0.027 \\
\hline & & $(0.004)^{\mathrm{a}}$ & $(0.005)$ & $(0.003)^{\mathrm{a}}$ & $(0.002)^{\mathrm{a}}$ & $(0.002)^{\mathrm{a}}$ \\
\hline $\begin{array}{l}\text { Hansen test (p- } \\
\text { value) }\end{array}$ & 0.06 & 0.36 & 0.14 & 1.00 & 1.00 & 1.00 \\
\hline $\begin{array}{l}\text { AR(2) test (p- } \\
\text { value) }\end{array}$ & 0.96 & 0.94 & 0.04 & 0.19 & 0.11 & 0.31 \\
\hline Observations & 9716 & 9716 & 12472 & 2556 & 3399 & 3761 \\
\hline
\end{tabular}

System GMM estimation

Dependent variable: $\log ($ employment)

Standard errors in parentheses

${ }^{\mathrm{c}}$ significant at $10 \%$; $^{\mathrm{b}}$ significant at $5 \%$; $^{\mathrm{a}}$ significant at $1 \%$

Linkage defined as inputs sourced in Ireland divided by total inputs

Definition of size classes:

small: employment less than 33 percentile (43 employees)

medium: employment between 33 and 66 percentile

large: employment larger than 66 percentile (99 employees) 
Table 4: Robustness checks: Considering exit in conditional labour demand

\begin{tabular}{|c|c|c|}
\hline & Only survivors & all firms with exit dummy \\
\hline \multirow[t]{2}{*}{ log employment (t-1) } & 0.832 & 0.821 \\
\hline & $(0.001)^{\mathrm{a}}$ & $(0.002)^{\mathrm{a}}$ \\
\hline \multirow[t]{2}{*}{ log employment (t-2) } & -0.069 & -0.063 \\
\hline & $(0.001)^{\mathrm{a}}$ & $(0.001)^{\mathrm{a}}$ \\
\hline \multirow[t]{2}{*}{ log wage } & -0.214 & -0.201 \\
\hline & $(0.006)^{\mathrm{a}}$ & $(0.007)^{\mathrm{a}}$ \\
\hline \multirow[t]{2}{*}{ log output } & 0.217 & 0.202 \\
\hline & $(0.002)^{\mathrm{a}}$ & $(0.003)^{\mathrm{a}}$ \\
\hline \multirow[t]{2}{*}{ linkage } & 0.415 & 0.212 \\
\hline & $(0.013)^{\mathrm{a}}$ & $(0.023)^{\mathrm{a}}$ \\
\hline \multirow[t]{2}{*}{ log wage * linkage } & 0.049 & 0.052 \\
\hline & $(0.008)^{\mathrm{a}}$ & $(0.011)^{\mathrm{a}}$ \\
\hline \multirow[t]{2}{*}{ log output * linkage } & -0.080 & -0.056 \\
\hline & $(0.003)^{\mathrm{a}}$ & $(0.005)^{\mathrm{a}}$ \\
\hline \multirow[t]{2}{*}{ foreign dummy } & 0.118 & 0.214 \\
\hline & $(0.012)^{\mathrm{a}}$ & $(0.015)^{\mathrm{a}}$ \\
\hline \multirow[t]{2}{*}{ log wage $*$ foreign } & -0.120 & -0.121 \\
\hline & $(0.005)^{\mathrm{a}}$ & $(0.007)^{\mathrm{a}}$ \\
\hline \multirow[t]{2}{*}{$\log$ output $*$ foreign } & 0.012 & 0.008 \\
\hline & $(0.002)^{\mathrm{a}}$ & $(0.003)^{\mathrm{a}}$ \\
\hline \multirow[t]{2}{*}{ log wage $*$ linkage $*$ foreign } & 0.038 & 0.036 \\
\hline & $(0.009)^{\mathrm{a}}$ & $(0.013)^{\mathrm{a}}$ \\
\hline \multirow[t]{2}{*}{ log output $*$ linkage $*$ foreign } & 0.017 & 0.012 \\
\hline & $(0.003)^{\mathrm{a}}$ & $(0.004)^{\mathrm{a}}$ \\
\hline \multirow[t]{2}{*}{ log wage * exit dummy } & & 0.056 \\
\hline & & $(0.018)^{\mathrm{a}}$ \\
\hline \multirow[t]{2}{*}{ log wage * linkage * exit dummy } & & -0.044 \\
\hline & & $(0.012)^{\mathrm{a}}$ \\
\hline \multirow[t]{2}{*}{ log wage * foreign * exit dummy } & & -0.220 \\
\hline & & $(0.012)^{\mathrm{a}}$ \\
\hline \multirow[t]{2}{*}{ log wage $*$ linkage $*$ foreign $*$ exit dummy } & & 0.019 \\
\hline & & $(0.013)$ \\
\hline \multirow[t]{2}{*}{ exit dummy } & & 0.069 \\
\hline & & $(0.035)^{b}$ \\
\hline Hansen test (p-value) & 0.38 & 0.32 \\
\hline AR(2) test (p-value) & 0.93 & 0.89 \\
\hline Observations & 8924 & 9444 \\
\hline
\end{tabular}

System GMM estimation

Dependent variable: $\log ($ employment)

Standard errors in parentheses

c significant at $10 \%$; ${ }^{\text {b }}$ significant at $5 \%$; ${ }^{\text {a }}$ significant at $1 \%$

Linkage defined as inputs sourced in Ireland divided by total inputs 
Figure 1:

Employment growth by nationality of ownership

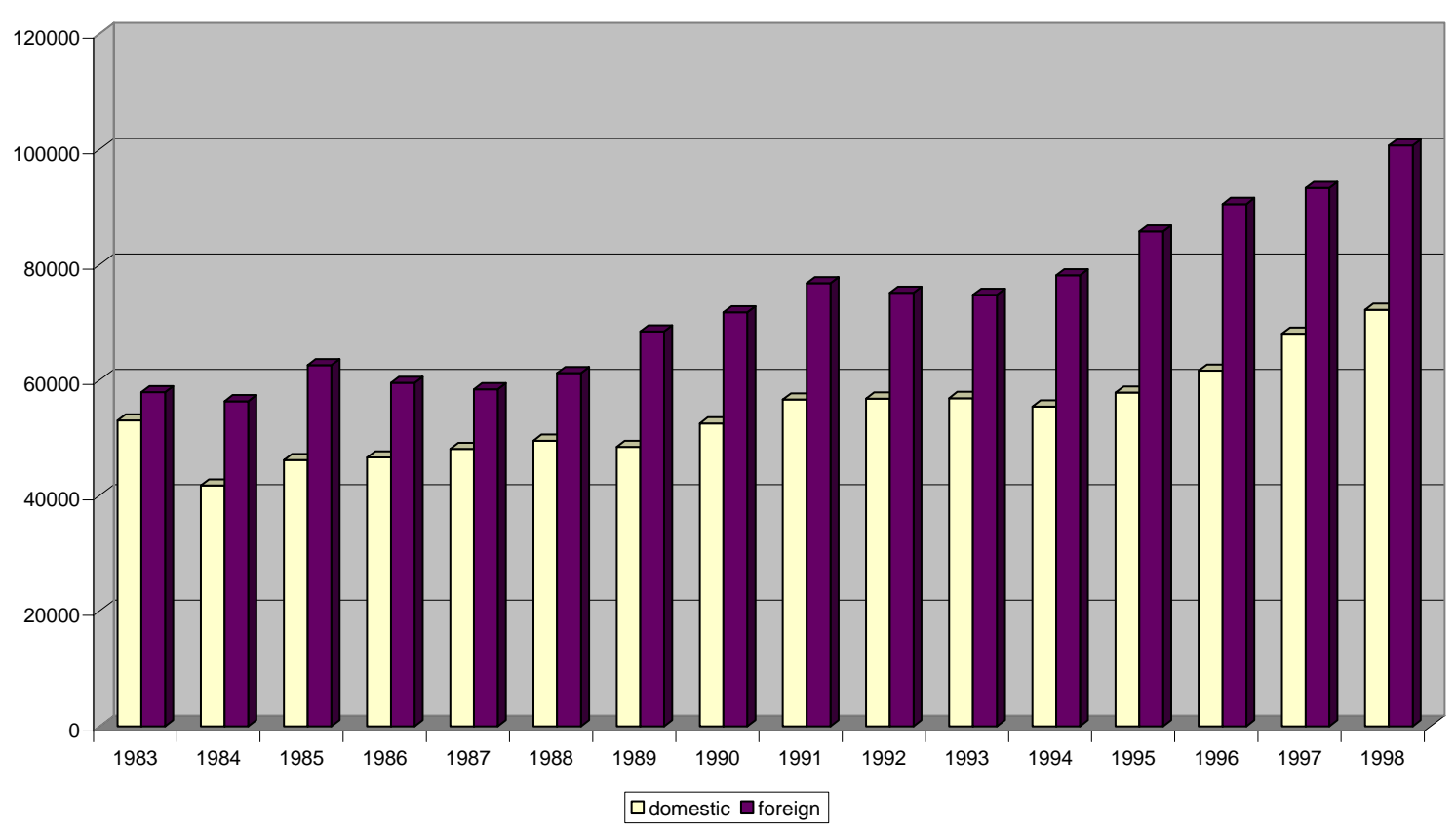


Appendix II: Comparison of different estimators

\begin{tabular}{|l|l|l|l|l|l|l|l|l|}
\hline & $(1)$ & $(2)$ & $(3)$ & $(4)$ & $(5)$ & $(6)$ & $(7)$ \\
\hline & ols & fe & dif & sys & ols & fe & dif & sys \\
\hline log employment (t-1) & 0.865 & 0.488 & 0.481 & 0.631 & 1.040 & 0.647 & 0.612 \\
\hline & $(0.006)^{\mathrm{a}}$ & $(0.006)^{\mathrm{a}}$ & $(0.039)^{\mathrm{a}}$ & $(0.026)^{\mathrm{a}}$ & $(0.017)^{\mathrm{a}}$ & $(0.011)^{\mathrm{a}}$ & $(0.058)^{\mathrm{a}}$ & $(0.037)^{\mathrm{a}}$ \\
\hline $\log$ employment (t-2) & & & & & -0.088 & -0.016 & -0.003 & -0.113 \\
\hline & & & & & $(0.016)^{\mathrm{a}}$ & $(0.008)^{\mathrm{b}}$ & $(0.023)$ & $(0.028)^{\mathrm{a}}$ \\
\hline $\log$ wage & -0.143 & -0.342 & -0.272 & -0.276 & -0.449 & -0.446 & -0.501 & -0.520 \\
\hline & $(0.009)^{\mathrm{a}}$ & $(0.008)^{\mathrm{a}}$ & $(0.091)^{\mathrm{a}}$ & $(0.046)^{\mathrm{a}}$ & $(0.033)^{\mathrm{a}}$ & $(0.009)^{\mathrm{a}}$ & $(0.099)^{\mathrm{a}}$ & $(0.071)^{\mathrm{a}}$ \\
\hline $\log$ output & 0.102 & 0.381 & 0.405 & 0.317 & 0.446 & 0.462 & 0.415 & 0.462 \\
\hline & $(0.005)^{\mathrm{a}}$ & $(0.005)^{\mathrm{a}}$ & $(0.048)^{\mathrm{a}}$ & $(0.027)^{\mathrm{a}}$ & $(0.023)^{\mathrm{a}}$ & $(0.006)^{\mathrm{a}}$ & $(0.061)^{\mathrm{a}}$ & $(0.069)^{\mathrm{a}}$ \\
\hline $\log$ wage (t-1) & & & & & 0.410 & 0.246 & 0.222 & 0.421 \\
\hline & & & & & $(0.034)^{\mathrm{a}}$ & $(0.010)^{\mathrm{a}}$ & $(0.064)^{\mathrm{a}}$ & $(0.062)^{\mathrm{a}}$ \\
\hline $\log$ output (t-1) & & & & & -0.413 & -0.186 & -0.082 & -0.343 \\
\hline & & & & & $(0.024)^{\mathrm{a}}$ & $(0.008)^{\mathrm{a}}$ & $(0.065)$ & $(0.069)^{\mathrm{a}}$ \\
\hline Hansen test (p-value) & & & 0.01 & 0.01 & & & 0.05 & 0.14 \\
\hline AR(2) test (p-value) & & & 0.02 & 0.05 & & & 0.06 & 0.90 \\
\hline Observations & 12474 & 12474 & 9717 & 12474 & 9717 & 9717 & 7752 \\
\hline
\end{tabular}

Dependent variable: $\log ($ employment)

Standard errors in parentheses

${ }^{\mathrm{c}}$ significant at $10 \%$; ${ }^{\mathrm{b}}$ significant at $5 \%$; ${ }^{\mathrm{a}}$ significant at $1 \%$ 